\title{
PENGARUH PERIODE PEMUASAAN TERHADAP EFISIENSI PEMANFAATAN PAKAN, PERTUMBUHAN DAN KELULUSHIDUPAN IKAN MAS (Cyprinus carpio)
}

\author{
Arifin Mustofa, Sri Hastuti, Diana Rachmawati \\ Program Studi Budidaya Perairan, Departemen Akuakultur \\ Fakultas Perikanan dan Ilmu Kelautan, Universitas Diponegoro
}

\begin{abstract}
ABSTRAK
Penelitian ini bertujuan untuk mengkaji pengaruh periode pemuasaan terhadap efisiensi pemanfaatan pakan,pertumbuhan, dan kelulushidupan pada ikan mas (C. carpio). Data yang diamati meliputi total konsumsi pakan (TKP), efisiensi pemanfaatan pakan (EPP), rasio konversi pakan (FCR), laju pertumbuhan relatif (RGR), pertumbuhan panjang mutlak, kelulushidupan (SR) dan kualitas air. Kegiatan penelitian ini dilaksanakanpada bulan April hingga bulan Juli 2017, di Balai Benih Ikan (BBI) Mijen, Semarang.Penelitian ini menggunakan metode experimental dengan rancangan acak lengkap (RAL) 4 perlakuan dan3 ulangan. Perlakuan yang diujikan adalah pemuasaan pemberian pakan dengan perlakuan A (pemberian pakan setiap hari), B (1 hari dipusakan 1 hari diberi pakan), C (1 hari dipuasakan 2 hari diberi pakan), dan D (1 hari dipuasakan 3 hari diberi pakan). Ikan uji yang digunakan adalah ikan mas $(C$. carpio)dengan panjang rata-rata $5,13 \pm 0,06 \mathrm{~cm}$ dan bobot rata-rata $3,01 \pm 0,10 \mathrm{~g}$. Pemberian pakan pada pukul 08.00 dan 16.00 secara at satiation. Ikan uji dipelihara dengan padat tebar 10 ekor/wadah. Wadah pemeliharaan menggunakan ember bervolume $25 \mathrm{~L}$, dengan lama pemeliharaan 72 hari. Pakan yang digunakan adalah pakan komersil berupa (pellet) dengan protein 32\%. Hasil penelitian menunjukkan bahwa metode pemuasaan berpengaruh nyata $(\mathrm{P}<0,05)$ terhadap TKP,EPP, FCR, RGR, dan pertumbuhan panjang mutlak, namun tidak berpengaruh nyata $(P>0,05)$ terhadap SR. Hasil perlakuan A (tanpa dipuasakan) memberikan nilai TKP tertinggi sebesar $126,30 \pm 5,25 \mathrm{~g}$, nilai RGR tertinggi sebesar

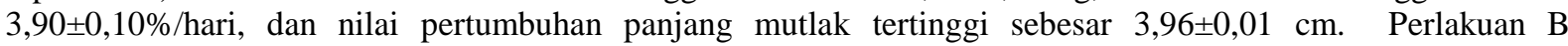
(dipuasakan 1 hari diikuti pemberian pakan 1 hari) memberikan nilai EPP tertinggi sebesar 76,44 $\pm 2,46 \%$, dan nilai FCR terrendah sebesar 1,22 $\pm 0,04$.
\end{abstract}

Kata kunci: Pemuasaan, Pemanfaatan Pakan, Pertumbuhan, C. carpio.

\begin{abstract}
The aims of this study is to examine the influence of the starving period on efficiency of feed utilization, growth, and survival in common carp (C. carpio). Observed data include feed consumption (FC), feed utilization efficiency (EPP), feed conversion ratio (FCR), relative growth rate (RGR), absolute longevity, survival rate (SR) and water quality.This study was conducted in April 2017 until July 2017, at Balai Benih Ikan (BBI) Mijen, Semarang. Method that used in this study was experimental withcomplete randomized design (CRD) 4 treatment and 3 replications. Treatment that used in this study wereA (daily fed), B (1 day starved, 1 day is fed), C ( 1 day starved 2 day is fed), and D ( 1 day is starved 3 day is fed). The fish that used were common carp (C. carpio) with an average length $5,13 \pm 0,06 \mathrm{~cm}$ and weight $3,01 \pm 0,10 \mathrm{~g}$. Feeding time was on 08.00 and 16.00 withatsatiation method. The fish was cultured with density 10 fish/tank. The water tank for treatment has a volume of 25 L.Treatment was done for 72 days. The feed used was commercial feed with $32 \%$ protein. The results showed that starving with different periods had significant effect $(\mathrm{P}<0.05)$ on FC, EPP, FCR, RGR, and absolute longevity, but no significant effect $(\mathrm{P}>0.05)$ on SR. Results of treatment A (no starving) gave the

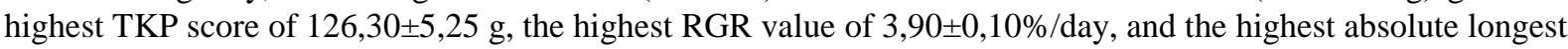
growth value of $3,96 \pm 0,01 \mathrm{~cm}$. Treatment B ( 1 day feed followed by 1 day feeding) gave the highest EPP score of $76,44 \pm 2,46 \%$, and the lowest FCR value was $1,22 \pm 0,04$.
\end{abstract}

Keywords: Starvation, Feed Utilization, Growth, C. carpio. 


\section{PENDAHULUAN}

Ikan mas (Cyprinus carpio) adalah salah satu jenis ikan yang mempunyai nilai ekonomis tinggi dan banyak dibudidayakan karena mempunyai daya adaptasi yang tinggi terhadap kondisi lingkungan, mudah untuk dipijahkan, tahan terhadap penyakit, pemakan segala, dan pertumbuhannya cepat (Supriatna, 2013). Hal ini didukung oleh Afifah et al. (2014) menyatakan bahwa ikan mas (Cyprinus carpio) merupakan salah satu jenis ikan air tawar yang sangat digemari oleh masyarakat Indonesia. Permintaan akan ikan konsumsi ini terus meningkat dan berkembang, ditandai dengan terus naiknya produksi jenis ikan mas setiap tahunnya. Kenaikan rata-rata produksi ikan mas pada tahun 2013 mencapai 7,00\%. Menurut (Widiastuti, 2009) bahwa ikan mas ( $C$. carpio) termasuk ikan yang memilki kemampuan adaptasi yang baik. Ikan ini mampu bertahan hidup dalam air yang suhunya mengalami perubahan ekstrim.

\section{Faktor Penyebab Penurunan Produksi}

Salah satu penyebab turunnya produksi pada kegiatan budidaya ikan mas secara intensif adalah pakan (Sanjayasari, 2010). Pakan ikan merupakan faktor penting dalam menunjang keberhasilan usaha budidaya, akan tetapi biaya yang dikeluarkan untuk pengadaan pakan relatif besar mencapai $35-70 \%$ dari total biaya produksi. Menurut Marwa et al. (2013) bahwa pada sektor budidaya, penyerapan nutrisi pakan yang belum optimal, merupakan salah satu permasalahan dalam kegiatan budidaya, sehingga pakan yang dikonsumsi ikan kurang dimanfaatkan secara efektif dan efisien untuk pertumbuhan. Pakan harus diberikan dengan manajemen yang tepat, mulai dari frekuensi maupun waktu pemberian pakannya. Ikan hanya menyerap sekitar $25 \%$ pakan yang diberikan, sedangkan $75 \%$ sisanya menetap sebagai limbah didalam air. Limbah dari pakan tersebut akan dimineralisasi oleh bakteri menjadi ammonia. Akumulasi ammonia dapat mencemari media budidaya bahkan dapat menyebabkan kematian.

\section{Pengaturan Pemberian Pakan}

Upaya yang banyak dilakukan saat ini dalam budidaya ikan adalah pengaturan cara pemberian pakan agar pakan yang diberikan dapat termanfaatkan secara optimal untuk pertumbuhan dan kelangsunganhidup. Manajemen pemberian pakan yang tepat akan memberikan hasil yang optimal pada pertumbuhan, meningkatkan efisiensi pemanfaatan pakan oleh ikan dan kualitas air tetap terjaga (Hanief et al. 2014). 
Metode untuk meningkatkan efisiensi pemanfaatan pakan dan mempercepat pertumbuhan adalah dengan cara pemberian pakan yang efektif, salah satunya adalah dengan cara pemuasaan pakan. Hal ini perkuat oleh Mulyani et al. (2014) bahwa pada pembudidayaan ikan dengan perlakuan pemuasaan (starving) yang dipelihara pada periode yang cukup atau satiation level, terjadi pertumbuhan yang cepat setelah periode starving. Kondisi ini dilakukan agar terjadi pertumbuhan yang cepat (compensatory growth) pada periode pemberian pakan (satiation level) setelah periode pemuasaan.

Penelitian yang dilakukan oleh Purbomartono et al. (2009) bahwa pada ikan nila merah yang dipuasakan menunjukan nilai konversi pakan dan pemanfaatan pakan lebih tinggi dari pada ikan yang tidak dipuasakan. Perlakuan dengan FCR (food convention ratio) terbaik pada perlakuan dua hari diberi makan dan satu hari dipuasakan yaitu 0,52 sedangkan nilai FCR ikan yang tidak dipuasakan adalah 0,77. Penelitian yang dilakukan Mulyani et al. (2014) bahwa pada ikan nila memiliki nilai efisiensi pakan yang lebih tinggi dari pada ikan yang tidak dipuasakan. Pada perlakuan satu hari diberi pakan dan satu hari dipuasakan mempunyai nilai efisiensi pakan $88,91 \%$ sedangkan pada ikan yang setiaap hari diberi pakan memiliki efisiensi pakan $83,41 \%$. Ikan yang dipuasakan juga memiliki pertumbuhan yang relatif sama bahkan lebih tinggi dari pada ikan nila yang tidak dipuasakan.

Penelitian ini bertujuan untuk mengkaji pengaruh periode pemuasaan terhadap efisiensi pemanfaatan pakan, pertumbuhan, dan kelulushidupan pada ikan mas (C. carpio).

\section{METODE PENELITIAN}

Ikan uji yang digunakan dalam penelitian ini adalah benih ikan mas $(C$. carpio) dengan ukuran panjang rata-rata $5,13 \pm 0,06 \mathrm{~cm} /$ ekor dan bobot rata-rata 3,01 $\pm 0,10$ g/ekor. Ikan mas (C. carpio) yang digunakan berjumlah 120 ekor dan diperoleh dari Balai Benih Ikan (BBI) Mijen, Semarang. Menurut Silvianti, (2015) bahwa percobaan dengan tiga ulangan dilakukan dengan menggunakan

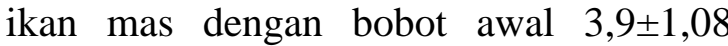
g/ekor. Wadah yang digunakan dalam penelitian ini berupa ember bervolume 25 L, dengan jumlah 12 unit. Padat tebar ikan uji dengan 10 ekor dalam satu ember wadah pemeliharaan. Hal ini diperkuat oleh Rudiyanti dan Astri, (2009) yang menyatakan bahwa jumlah ikan yang digunakan pada masing-masing wadah adalah 10 ekor. 
Pakan uji yang digunakan pada penelitian ini adalah pakan uji berupa pakan komersil berbentuk (pellet) dengan kandungan protein $32 \%$ dan berdiameter 2 mm.Hal ini didukung oleh Mudlofar et al.(2013) yang menyatakan bahwa pakan yang diberikan pada benih ikan mas berupa pellet (pakan buatan), kandungan protein 30-35\%, lemak 6-8\% (bobot kering). Pakan diberikan sesuai dengan jadwal pemuasaan pada setiap perlakuan. Frekuensi pemberian pakan adalah 2 kali sehari pada pukul 08.00 dan 16.00 dengan metode at-satiation. Menurut Gusman dan Muhammad, (2014) yang menyatakan bahwa pakan diberikan menurut perlakuan yang telah ditetapkan secara acak, frekuensi pemberian sebanyak 2 kali sehari yaitu pada pukul 8.00 dan 16.00.

Penelitian ini dilakukan secara eksperimen menggunakan rancangan acak lengkap (RAL) dengan 4 perlakuan dan 3 ulangan, selama 72 hari.Menurut Widyantoro et al. (2014) bahwa penelitian yang dilakukan menggunakan 4 perlakuan 3 ulangan. Perlakuan pada penelitian ini didasarkan pada hasil uji pendahuluan sebelumnya yaitu penelitian Mulyani et al. (2014) bahwa dengan perlakuan satu hari pemuasaaan dan tiga hari diberi pakan memeiliki varibel pertumbuhan, efisiensi pemanfaatan pakan, dan kelulushidupan yang terbaik. Masing-masing perlakuan pada penelitian ini adalah sebagai berikut :

Perlakuan A : ikan diberi pakan setiap hari tanpa adanya pemuasaan selama 72 hari pemeliharaan.

Perlakuan B : ikan dipuasakan 1 hari diikuti pemberian pakan 1 hari selama 72 hari pemeliharaan.

Perlakuan C : ikan dipuasakan 1 hari diikuti pemberian pakan 2 hari selama 72 hari pemeliharaan.

Perlakuan D : ikan dipuasakan 1 hari diikuti pemberian pakan 3 hari selama 72 hari pemeliharaan.

Tata letak wadah untuk setiap ulangan ditempatkan secara acak (random). Menurut Juwitanti et al. (2013) bahwa rancangan acak lengkap adalah rancangan percobaan yang paling sederhana, rancangan ini dicirikan dengan diberikannya perlakuan secara acak pada seluruh materi atau unit percobaan. Penelitian ini dilakukan dengan memuasakan ikan secara periodik sesuai dengan perlakuan. Satu periode pemuasaan terjadi selama 12 hari, karena setelah 12 hari siklus pemuasaan kembali ke semula. Penelitian ini dilakukan selama 
6 siklus (72 hari). Jadwal periode pada Tabel 1.

pemuasaan dalam satu siklus dapat dilihat

Tabel 1. Jadwal Satu Siklus Periode Pemuasaan Ikan Mas (C. carpio)

\begin{tabular}{cccccccccccccc}
\hline \multirow{2}{*}{ Perlakuan } & \multicolumn{10}{c}{ Hari Ke } \\
\cline { 2 - 15 } & 1 & 2 & 3 & 4 & 5 & 6 & 7 & 8 & 9 & 10 & 11 & 12 & ..dst. Ke-72 \\
\hline A & V & V & V & V & V & V & V & V & V & V & V & V & V \\
B & V & - & V & - & V & - & V & - & V & - & V & - & - \\
C & V & V & - & V & V & - & V & V & - & V & V & - & - \\
D & V & V & V & - & V & V & V & - & V & V & V & - & - \\
\hline
\end{tabular}

Keterangan : $\mathrm{V}=$ Ikan diberi pakan

- = Ikan dipuasakan

\section{Pengumpulan Data}

Variabel yang diukur meliputi nilai tingkat konsumsi pakan (TKP), efisiensi pemanfaatan pakan (EPP), rasio konversi pakan (FCR), laju pertumbuhan bobot relatif (RGR), pertumbuhan panjang mutlak (PM), dan kelulushidupan (SR). Data kualitas air diukur meliputi DO, pH, suhu, dan ammonia.

\section{Total Konsumsi Pakan}

MenurutPereira et al. (2007) total konsumsi pakan (TKP) dihitung dengan menggunakan rumus sebagai berikut:

$$
\mathrm{TKP}=\mathrm{F} 1-\mathrm{F} 2
$$

dimana:

$$
\begin{array}{ll}
\text { TKP } & =\text { Tingkat konsumsi pakan } \\
\text { F1 } & =\text { Jumlah pakan awal }(\mathrm{g}) \\
\text { F2 } & =\text { Jumlah pakan sisa }(\mathrm{g})
\end{array}
$$

\section{Efisiensi Pemanfaatan Pakan}

Menurut Tacon (1987),nilaiefisiensi pemanfaatan pakan (EPP) dihitung dengan rumus sebagai berikut:

$$
\mathrm{EPP}=\frac{W t-W 0}{\mathrm{~F}} \times 100 \%
$$

dimana:

$$
\begin{aligned}
\mathrm{EPP}= & \text { Efisiensi pemanfaatan pakan }(\%) \\
\mathrm{W}_{\mathrm{t}}= & \text { Bobot total ikan pada akhir } \\
& \text { penelitian }(\mathrm{g}) \\
\mathrm{W}_{\mathrm{o}}= & \text { Bobot total ikan pada awal } \\
& \text { penelitian }(\mathrm{g}) \\
\mathrm{F}= & \begin{array}{l}
\text { Jumlah pakan yang dikonsumsi } \\
\text { selama penelitian }(\mathrm{g})
\end{array}
\end{aligned}
$$

\section{Rasio Konversi Pakan}

Menurut Tacon (1987), bahwa rasio konversi pakan (FCR) dihitung berdasarkan rumus sebagai berikut:

$$
\mathrm{FCR}=\frac{\mathrm{F}}{(W t+D)-W 0}
$$

dimana :

$$
\begin{aligned}
\mathrm{FCR}= & \text { Rasio konversi pakan } \\
\mathrm{F}= & \text { Jumlah pakan uji yang } \\
& \text { dikonsumsi selama penelitian }(\mathrm{g})
\end{aligned}
$$




$$
\begin{aligned}
\mathrm{Wt}= & \text { Bobot total ikan ujipada akhir } \\
& \text { pemeliharaan }(\mathrm{g}) \\
\mathrm{D}= & \text { Bobot total ikan uji yang mati }(\mathrm{g}) \\
\mathrm{Wo}= & \begin{array}{l}
\text { Bobot total ikan uji pada awal } \\
\text { pemeliharaan }(\mathrm{g})
\end{array}
\end{aligned}
$$

\section{Laju Pertumbuhan Relatif}

Menurut Subandiyono dan Hastuti (2014) laju pertumbuhan bobot relatif atau relative growth rate (RGR) ikan dihitung menggunakan rumus sebagai berikut:

$$
\mathrm{RGR}=\frac{W t-W 0}{W 0 \times t} \times 100 \%
$$

dimana:

$$
\begin{aligned}
\mathrm{RGR}= & \text { Laju pertumbuhan bobot relatif } \\
& (\% \text { per hari }) \\
\mathrm{Wt}= & \begin{array}{l}
\text { Bobot total ikan pada akhir } \\
\text { pemeliharaan }(\mathrm{g})
\end{array} \\
\mathrm{Wo}= & \begin{array}{l}
\text { Bobot total ikan pada awal } \\
\text { pemeliharaan }(\mathrm{g})
\end{array} \\
\mathrm{t}= & \text { Waktu pemeliharaan (hari) }
\end{aligned}
$$

\section{Pertumbuhan Panjang Mutlak}

Menurut Effendie

(1997), pertumbuhan panjang mutlak ikan dihitung dengan rumus sebagai berikut:

$$
\mathrm{Pm}=\mathrm{Lt}-\mathrm{Lo}
$$

dimana :

$\mathrm{Pm}=$ Pertumbuhan panjang mutlak $(\mathrm{cm})$

Lt $=$ Panjang rata-rata akhir $(\mathrm{cm})$

$\mathrm{L} 0=$ Panjang rata-rata awal $(\mathrm{cm})$

\section{Kelulushidupan}

Menurut Alamsjah

(2013)

kelulushidupan dapat dihitung berdasarkan rumus sebagai berikut :

$$
\mathrm{SR}=\frac{N t}{N 0} \times 100 \%
$$

dimana:

$\mathrm{SR}=$ Tingkat kelulushidupanikan (\%)

$\mathrm{N}_{\mathrm{t}} \quad=$ Jumlah ikan pada akhir penelitian (ekor)

$\mathrm{N}_{0}=$ Jumlah ikan padaawal penelitian (ekor)

\section{Parameter Kualitas air}

Parameter data kualitas air yang diukur meliputi DO, $\mathrm{pH}$, suhu, dan amonia. DO diukur menggunakan DO meter.pH diukur menggunakan $\mathrm{pH}$ meter. Suhu diukur menggunakan thermometer. Pengukuran amonia dilakukan di laboratorium teknik lingkungan, UNDIP. Pengukuran DO, $\mathrm{pH}$, suhu dilakukan 1 minggu sekali dandilakukan pada setiap perlakuan. Amonia di ukur di awal, tengah, akhir penelitiaan dan dilakukan pada wadah perlakuan A2, B2, C1, dan D3.

\author{
Analisis Data \\ Analisa data yang dilakukan meliputi \\ nilai tingkat konsumsi pakan (TKP), \\ efisiensi pemanfaatan pakan (EPP), rasio \\ konversi pakan (FCR), laju pertumbuhan \\ bobot relatif (RGR), pertumbuhan panjang
}


mutlak (PM),kelulushidupan (SR), dan kualitas air.Variabel yang didapatkan kemudian dilakukan uji normalitas, uji homogenitas, dan uji adivitas guna mengetahui bahwa data bersifat normal, homogen dan aditif sebagai syarat uji lebih lanjut yaitu analisa ragam. Data nilai tingkat konsumsi pakan (TKP), efisiensi pemanfaatan pakan (EPP), rasio konversi pakan (FCR), laju pertumbuhan bobot relatif (RGR), pertumbuhan panjang mutlak (PM), dan kelulushidupan (SR)dianalisis menggunakan analisis sidik ragam (ANOVA). Apabila data berpengaruh nyata dilanjutkan uji Duncan selang kepercayaan 95\%. Data kualitas air dianalisis secara deskriptif.

\section{HASIL DAN PEMBAHASAN}

Hasil penelitian pengaruh periode pemuasaan terhadap nilai tingkat konsumsi pakan (TKP), efisiensi pemanfaatan pakan (EPP), rasio konversi pakan (FCR), laju pertumbuhan bobot relatif (RGR), pertumbuhan panjang mutlak (PM), dan kelulushidupan (SR) yang tersaji pada Tabel2.

Berdasarkan data nilai TKP, EPP, FCR, RGR, pertumbuhan panjang mutlak, dan SR pada ikan mas (C. carpio) selama pemeliharaan dibuat grafik pada Gambar 1 .

Tabel 2. Nilai Rata-rata TKP, EPP, FCR, RGR, PM,dan SRpada Ikan Mas (C. carpio)Selama Pemeliharaan

\begin{tabular}{ccccccc}
\hline \multirow{2}{*}{$\begin{array}{c}\text { Perla } \\
\text {-kuan }\end{array}$} & TKP $(\mathrm{g})$ & EPP $(\%)$ & FCR & RGR (\%/hari) & $\begin{array}{c}\text { PertumbuhanP } \\
\text { anjang } \\
\text { Mutlak }(\mathrm{cm})\end{array}$ & SR (\%) \\
& & & & & & \\
\hline A & $126,30 \pm 5,25^{\mathrm{d}}$ & $65.40 \pm 1.64^{\mathrm{a}}$ & $1.40 \pm 0.10^{\mathrm{c}}$ & $3.90 \pm 0.10^{\mathrm{c}}$ & $3.96 \pm 0,01^{\mathrm{c}}$ & $90.10 \pm 10.00^{\mathrm{a}}$ \\
B & $68,63 \pm 1,75^{\mathrm{a}}$ & $76.44 \pm 2.46^{\mathrm{c}}$ & $1.22 \pm 0.04^{\mathrm{a}}$ & $2.42 \pm 0.14^{\mathrm{a}}$ & $2.87 \pm 0,21^{\mathrm{a}}$ & $93.33 \pm 5.77^{\mathrm{a}}$ \\
C & $86,27 \pm 4,43^{\mathrm{b}}$ & $74.29 \pm 0,78^{\mathrm{bc}}$ & $1.31 \pm 0.06^{\mathrm{b}}$ & $2.92 \pm 0.18^{\mathrm{b}}$ & $3.35 \pm 0.20^{\mathrm{b}}$ & $96.67 \pm 5.77^{\mathrm{a}}$ \\
D & $98,95 \pm 0,98^{\mathrm{c}}$ & $70.57 \pm 3.11^{\mathrm{b}}$ & $1.38 \pm 0.03^{\mathrm{c}}$ & $3.16 \pm 0.15^{\mathrm{b}}$ & $3.45 \pm 0,15^{\mathrm{b}}$ & $96.67 \pm 5.77^{\mathrm{a}}$ \\
\hline
\end{tabular}

Keterangan : Nilai data kolom yang berbeda dengan huruf superscript yang berbeda menunjukan hasil yang berbeda nyata $(\mathrm{P}<0,05)$ 


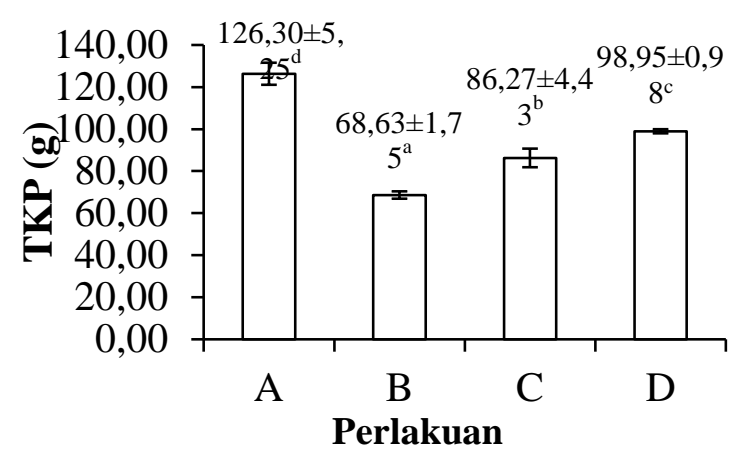

(A)

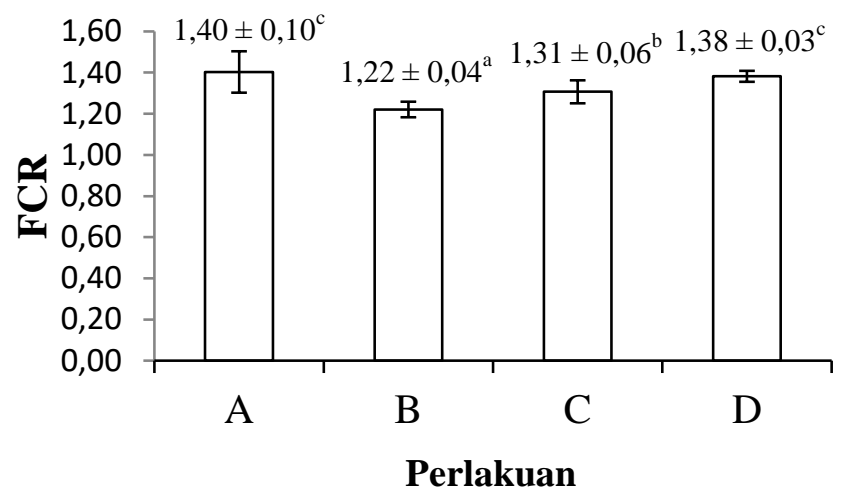

(C)

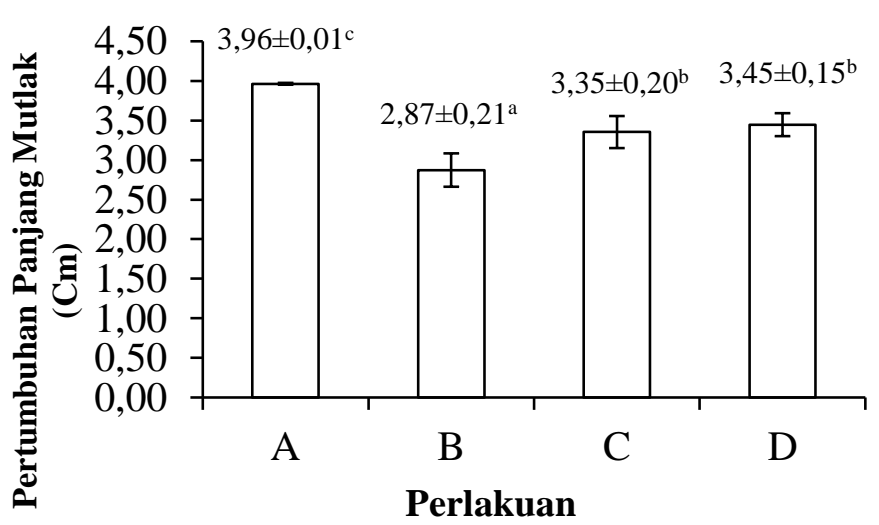

(E)

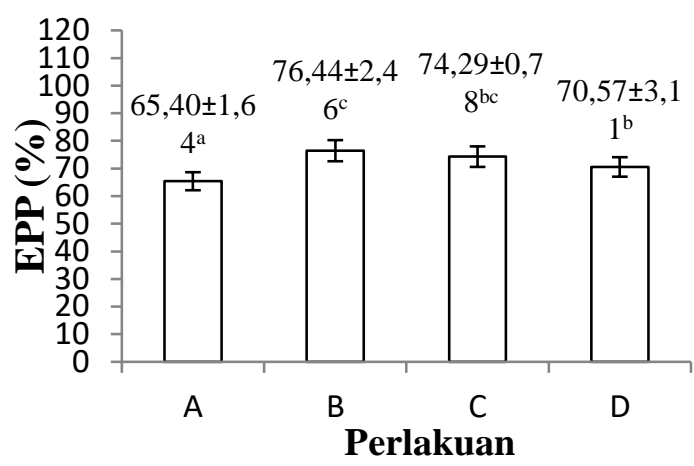

(B)

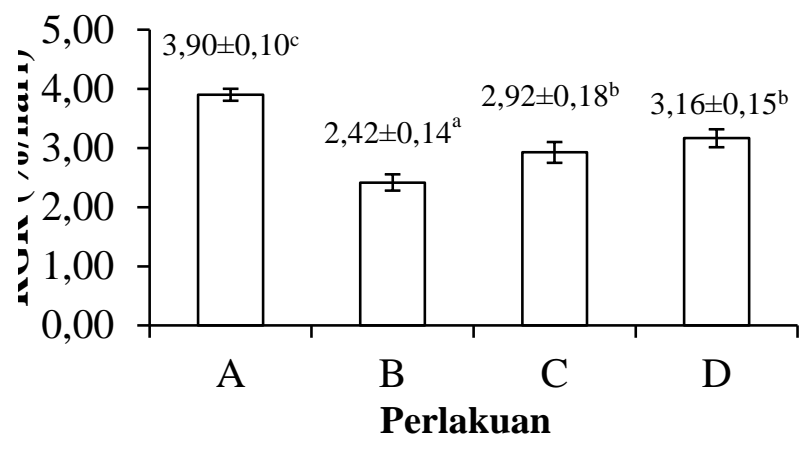

(D)

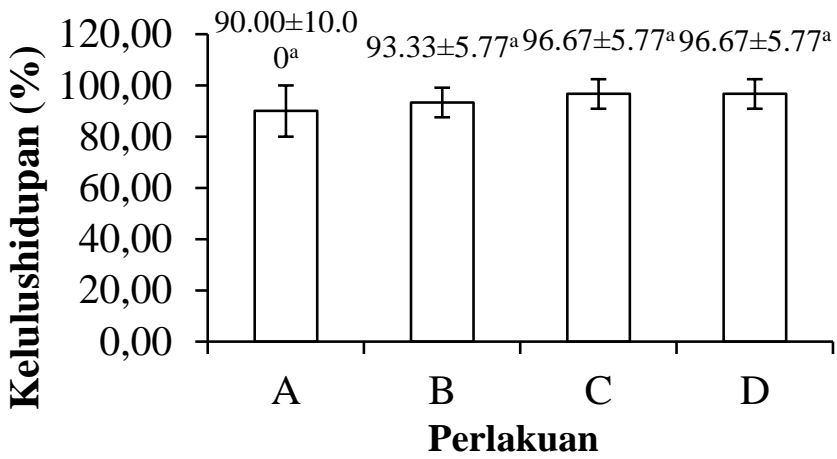

(F)

Gambar 1. Nilai Total Konsumsi Pakan (A), Efisiensi Pemanfaatan Pakan (B), Rasio Konversi Pakan (C), Laju Pertumbuhan Bobot Relatif (D), Pertumbuhan Panjang Mutlak (E), dan Kelulushidupan (F) pada Ikan Mas (C. carpio) Selama Pemeliharaan. 
Hasil analisis ragam menunjukan bahwa pemuasaan pada ikan mas $(C$. carpio) memberikan pengaruh yang nyata $(\mathrm{P}<0,05)$ terhadap nilai TKP, EPP, FCR, RGR dan PM namun tidak berpengaruh nyata $(\mathrm{P}>0,05)$ terhadap nilai SR.Hasil pengukuran parameter kualitas air pada media pemeliharaan ikan mas $(C$. carpio)selama penelitian tersaji pada Tabel 3.

Tabel 3. Hasil Pengukuan Parameter Kualitas Air pada Media PemeliharaanIkan Mas (C. carpio)Selama Penelitian

\begin{tabular}{ccccc}
\hline \multirow{2}{*}{ Perlakuan } & \multicolumn{4}{c}{ Kisaran Nilai Parameter Kualitas Air } \\
\cline { 2 - 5 } & Suhu $\left({ }^{0} \mathrm{C}\right)$ & $\mathrm{pH}$ & $\mathrm{DO}(\mathrm{mg} / \mathrm{L})$ & $\mathrm{NH}_{3}(\mathrm{mg} / \mathrm{L})$ \\
\hline A & $27-28$ & $8,12-8,45$ & $6,4-7,5$ & $0-0,0014$ \\
B & $27-28$ & $8,21-8,78$ & $6,3-7,3$ & $0-0,0011$ \\
C & $27-28$ & $8,19-8,72$ & $6,2-7,8$ & $0-0,0002$ \\
D & $27-28$ & $8,12-8,71$ & $6,4-7,2$ & $0-0,0023$ \\
Pustaka (Kelayakan) & $25-30^{\circ} \mathrm{C}^{*}$ & $6,5-9^{*}$ & $>5 \mathrm{mg} / \mathrm{L}^{*}$ & $0,7-2,4 \mathrm{mg} / \mathrm{L}^{*}$ \\
\hline
\end{tabular}

Keterangan: *Boyd, (1990)

Berdasarkan hasil penelitian yang telah dilakukan, periode pemuasaan yang diikuti pemberian pakan yang cukup terbukti mampu meningkatkan efektifitas pemanfaatan pakan, namun tidak mempercepat pertumbuhan pada ikan mas (C. carpio). Periode pemuasaan tetapi tidak berpengaruh nyata terhadap kelulushidupan ikan mas (C. carpio).

\section{Pemanfaatan Pakan}

Hasil anlisis ragam data total konsumsi pakan pada ikan mas (C. carpio) yang dipuasakan dengan periode berbeda menunjukkan hasil pengaruh yang nyata $(\mathrm{P}<0,05)$. Nilai total konsumsi pakan pada ikan mas (C. carpio) tertinggi adalah perlakuan A(ikan diberian pakan setiap hari) dan yang terendah adalah perlakuan B (ikan dipuasakan 1 hari diikuti pemberian pakan 3 hari).Ikan mas $(C$. carpio) yang tidak mengalami siklus pemusaan memiliki nilai TKP yang lebih tinggi dibandingkan ikan mas $(C$. carpio)yang mengalami siklus pemuasaan. Perlakuan D (ikan dipuasakan 1 hari diikuti pemberian pakan 3 hari) memiliki nilai TKP yang paling tinggi dibanding dengan perlakuan lain yang mengalami siklus pemuasaan. Hal tersebut diduga bahwa perlakuan B (ikan dipuasakan 1 hari diikuti pemberian pakan 1 hari) sering mengalami periode pemuasaan, sehingga nilai TKP yang dihasilkan paling rendah. Hal ini didukung oleh Sunarto dan Sabariah, (2012) yang menyatakan bahwa nilai konsumsi pakan yang rendah menunjukan bahwa tingkat efesiensinya lebih tinggi dalam memanfaatkan makanan untuk pertumbuhan. Sedangkan nilai konsumsi pakan yang tinggi menunjukan 
bahwa tingkat efesiensinya lebih rendah dalam memanfaatkan makanan untuk pertumbuhan.

Respon hiperfagia terbukti pada data (Lampiran 25) yang didapat pada perlakuan B (ikan dipuasakan 1 hari diikuti pemberian pakan 1 hari) dibandingkan dengan perlakuan A (ikan diberi pakan setiap hari). Data pada hari ke-25 sampai dengan hari ke-72 bahwa konsumsi pakan harian perlakuan B (ikan dipuasakan 1 hari diikuti pemberian pakan 1 hari) saat diberi pakan kembali memiliki jumlah konsumsi pakan harian yang lebih banyak dibandingkan dengan perlakuan A (ikan didiberi pakan setiap hari). Hal ini didukung oleh Mulyani et al. (2014) bahwa respon hiperfagia yang ditunjukkan oleh ikan pada saat pemberian pakan kembali, hal tersebut memungkinkan ada kaitannya dengan aktivitas enzim proteolitik yang berada pada saluran pencernaan terutama lambung, pada saat ikan dipuasakan enzim proteolitik bersifat enaktivasi dan lambung pada kondisi ketiadaan pakan (kosong) sehingga untuk memenuhi kebutuhan nutrisi ikan yang dipuasakan akan mengkonsumsi pakan lebih banyak dari kondisi normal (tidak dipuasakan). Hal ini didukung oleh Hanum et al. (2013) yang menyatakan bahwa pada kondisi puasa atau tidak diberi pakan akan menjadikan ketiadaan senyawa penginduksi sekresi dan aktivitas enzim dan pada saat ikan diberi pakan kembali, pakan yang ada pada saluran digesti akan bertindak sebagai penginduksi aktivitas enzim.

Berdasarkan hasil nilai efisiensi pemanfatan pakan selama pemeliharaan, didapatkan hasil tertinggi adalah perlakuan B (ikan dipuasakan 1 hari diikuti pemberian pakan 1 hari) dengan nilai $76,44 \pm 2,46 \%$. Nilai efisiensi pemanfaatan pakan (EPP) terendah adalah perlakuan A dengan nilai $65,40 \pm 1,64 \%$. Nilai EPP pada setiap perlakuan dalam penelitian ini dinyatan baik karena semua perlakuan memiliki nilai EPP mendekati $100 \%$ dan melebihi 50\%. Hal ini diperkuat olehPuspasari et al. (2015) efisiensi pemanfaatan pakan yang baik adalah lebih dari $50 \%$ atau bahkan mendekati $100 \%$.

Hasilanalisis ragam menunjukkan data EPP ikan mas (C. carpio) yang diberi daur pemuasaan dengan periode berbeda berpengaruh nyata. Hasil nilai EPP pada perlakuan B (ikan dipuasakan 1 hari diikuti pemberian pakan 1 hari) merupakan hasil yang tertinggi. Diduga pada perlakuan B adalah perlakuan yang paling sedikit jumlah pakan yang di konsumsi, sehingga ikan uji dalam memanfaatkan pakan dengan sebaik mungkin. Hal ini didukung oleh Yuwono et al. (2005) yang 
menyatakan bahwa nafsu makan yang meningkat mangakibatkan pakan dimanfaatkan secara efisien. Efiseiensi penggunaan pakan mengalami peningkatan pada ikan yang mengalami daur ulang puasa satu hari bahkan daur tiga hari diikuti dengan pemberian pakan kembali yang cukup. Namun, efisiensi pakan menurun jika ikan dipuasakan lebih dari tiga hari. Menurut Maulidin et al. (2016) bahwa nilai EPPyang baikmenunjukan bahwa pakan yang dikonsumsi memiliki kualitas yang baik, sehingga dapat dengan mudah dicerna dan dimanfaatkan secara efisien oleh ikan. Efisiensi pemanfaatan pakan sangat berhubungan erat dengan daya cerna ikan terhadap pakan yang diberikan. Menurut Yanti et al. (2013) daya cerna ikan terhadap suatu pakan dipengaruhi oleh beberapa faktor, yaitu sifat kimia air, suhu air, jenis pakan, ukuran dan umur ikan, kandungan nutrisi pakan, frekuensi pemberian pakan serta jumlah dan macam enzim pencernaan yang terdapat dalam saluran pencernaan pakan.

Berdasarkan rerata hasil nilai FCR pada ikan mas (C. carpio) selama penelitian diperoleh nilai tertinggi pada perlakuan A (ikan diberi pakan setiap hari) dengan rerata $1,40 \pm 0,10$. Nilai FCR paling rendah adaalah perlakuan B (ikan dipuasakan 1 hari diikuti pemberian pakan 1 hari) sebesar $1,22 \pm 0,04$. Kualitas suatu pakan tidak hanya dilihat dari nilai efisiensi pakan, tetapi juga dapat ditunjukkan dari nilai konversi pakan.Nilai FCR menunjukkan seberapa besar pakan yang dikonsumsi menjadi biomassa tubuh ikan. Nilai konversi pakan menunjukan efisiensi pemanfaatan nutrisi pakan oleh ikan. Semakin rendah nilai konversi pakan yang dihasilkan menunjukan penggunaan pakan tersebut semakin efisien. Hal ini didukung oleh Sulawesty et al. (2014) yang menyatakan bahwa rasio konversi pakan menunjukkan keefisienan dalam pemberian pakan. Nilai yang makin rendah menunjukkan bahwa makanan yang dapat dimanfaatkan dalam tubuh lebih baik dan kualitas makanannya lebih baik juga, karena dengan pemberian sejumlah pakan yang sama akan memberikan pertambahan berat tubuh yang lebih tinggi. Hasil FCR semua perlakuan selama penelitian dinyatakan baik karena kurang dari 1,5. Menurut Gusman dan Muhammad, (2014) yang menyatakan bahwa hasil penelitian rasio konversi pakan ikan mas berkisar antara 1,2-1,6. Nilai konversi pakan rendah menunjukkan pakan tersebut efisien untuk pertumbuhan ikan, semakin tinggi nilai konversi pakan menunjukkan bahwa pakan yang diberikan tidak efektif dalam pertumbuhan. Menurut Purbomartono et al. (2009) bahwa perlakuan dengan dipuasakan mempunyai nilai FCR yang 
terbaik yaitu pada perlakuan satu hari diberi pakan satu hari tidak diberi pakan, serta FCR terburuk terjadi pada perlakuan setiap hari diberi pakan atau kontrol sebesar 2,96.

\section{Pertumbuhan}

Berdasarkan rerata hasil laju pertumbuhan relatif pada ikan mas $(C$. carpio) selama penelitian diperoleh nilai tertinggi pada perlakuan A (ikan diberi pakan setiap hari) dengan rerata $3,90 \pm 0,10 \% /$ hari dan paling rendah adalah perlakuan B (ikan dipuasakan 1 hari diikuti pemberian pakan 1 hari) sebesar 2,42 $\pm 0,14$ \%/hari. Hasil analisis ragam data RGR padaikan mas (C. carpio)yang dipuasakan dengan periode berbeda menunjukkan hasil pengaruhnyata $(\mathrm{P}<0,05)$. Perlakuan $\mathrm{B}$ (ikan dipuasakan 1 hari diikuti pemberian pakan 1 hari) diduga mengalami penurunan pertumbuhan karena paling banyak mengalami pemuasaan. Menurut Purbomartono et al. (2009) bahwa perlakuan tiga hari diberi pakan satu hari tidak diberipakan (P3) dengan nilai sebesar $0,95 \pm 0,60 \mathrm{~g}$ berbedanyata dengan perlakuan sehari diberi pakan sehari tidakdiberi pakan (P1) yaitu $0,42 \pm 27 \mathrm{~g}$. Hal ini menunjukkanbahwa ikan yang satu hari diberi pakan satu hari tidakdiberi pakan mengalami penurunan pertumbuhan yanglebih nyata.
Namun kurangnya siklus pemberian pakan membuat pertumbuhanya terhambat. Berbeda dengan perlakuan yang diberi pakan setiap hari. Menurut Tribina, (2012) bahwa jika kebutuhan untuk pemeliharaan (maintenance) yang melebihi darijumlah pakanyang diberikan, maka akan terjadi proses pembongkaran energi dalam tubuh ikanitu sendiri (katabolisme). Jumlah pakan yang cukup bagi ikan artinya cukupuntuk pemeliharaan tubuh, aktivitas harian maupun pertumbuhanikan, jika terjadi kelebihan atau kekurangan pakan dapat mengakibatkan laju pertumbuhan menurun. Perlakuan B (ikan dipuasakan 1 hari diikuti pemberian pakan 1 hari) dan perlakuan $\mathrm{C}$ (ikan dipuasakan 1 hari diikuti pemberian pakan 2 hari) mempunyai nilai EPP yang tinggi namun nilai RGR rendah. Hal ini diduga karena ikan yang dipuasakan mengalami percepatan kapasitas pencernaan, namun tidak diimbangi pemberian frekuensi pemberian pakan yang cukup (Zaldua dan Naya, 2014). Menurut Purbomartono et al. (2009) bahwa ikan nila merah yang dipuasakan mengalami pengurangan nutrisi yang digunakan sebagai pertumbuhan. Bahwa ikan membutuhkan makanan untuk mendapatkan energi tubuh dan ikan akan mengalami penurunan energi tubuh yang lebihnyata jika ikan dipelihara dalam 
waktu yang lebih lamadalam kondisi kelaparan (dipuasakan).

Berdasarkan hasil nilai pertumbuhan panjang mutlak selama penelitian didapatkan hasil tertinggi pada perlakuan A (ikan diberi pakan setiap hari) sebesar $3,96 \pm 0,01 \mathrm{~cm}$ dan hasil terendah pada perlakuan B (ikan dipuasakan 1 hari diikuti

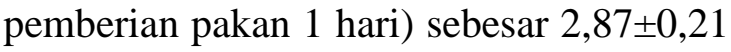
$\mathrm{cm}$. Hasil analisis ragam data pertumbuhan panjang relatif pada ikan mas (C. carpio) yang dipuasakan dengan periode berbeda menunjukkan hasil pengaruh nyata $(\mathrm{P}<0,05)$. Lebih tingginya pertumbuhan panjang mutlak pada perlakuan A (ikan diberi pakan setiap hari) dibanding perlakuan B (ikan dipuasakan 1 hari diikuti pemberian pakan 1 hari), memungkinkan ikan uji pada lebih sedikit mengkonsumsi pakan. Hal ini didukung oleh Purbomartono et al. (2009) bahwa hasil pengukuran laju pertambahan panjang memberikan hasil perlakuan pemberian pakan setiaphari atau (P4) menunjukkan angka pertumbuhan panjang tertinggi yaitu $1,96 \pm 1,39 \mathrm{~cm}$ dan perlakuan dua hari diberi pakan satu hari tidak diberi pakan (P2) menunjukkan angka pertambahan panjang terendah yaitu $1,35 \pm 0,95 \mathrm{~cm}$.

Nilai pertumbuhan panjang mutlak pada perlakuan B (ikan dipuasakan 1 hari diikuti pemberian pakan 1 hari) yang lebih redah dari perlakuan A (ikan diberi pakan setiap hari) diduga karena ikan mas yang dipuasakan mengalami pengurangan nutrisi. Hal ini diduga ikan mas yang dipuasakan mengalami pertumbuhan kompensatori. Pertumbuhan kompensatori dilaporkan oleh Mulyani et al. (2014) bahwa padaikan nila yang dipuasakan menunjukkan petumbuhan yang lebih baik dari pada ikan yang tidak dipuasakan. Menurut Yuwono et al. (2005) bahwa ikan gurame yang dipuasakan selama satu hari dan diberi pakan kembali akan mengalami pertumbuhan kompensatori sempurna.

\section{Kelulushidupan}

Berdasarkan pengamatan yang dilakukan terhadap nilai kelulushidupan pada ikan mas (C. carpio) yang dipuasakan dengan periode berbeda didapatkan hasil pada perlakuan $\mathrm{A}, \mathrm{B}, \mathrm{C}$, dan $\mathrm{D}$ secara berurutan adalah $90,10 \pm 10.00 \%$; $93,33 \pm 5,77 \% ; \quad 96,67 \pm 5,77 ; \quad$ dan $96,67 \pm 5,77 \%$. Hasil analisis ragam data kelulushidupan pada ikan mas (C. carpio) yang dipuasakan dengan periode berbeda menunjukkan hasil tidak pengaruh nyata $(\mathrm{P}<0,05)$. Rerata nilai kelulushidupan pada penelitian ini bisa dikatakan baik karena lebih dari $80 \%$ pada setiap perlakuan. Tingkat kelulushidupan diduga berkaitan dengan kualitas air sebagai media pemeliharaan, karena kualitas air yang 
optimum akan menghasilkan tingkat kelulushidupan yang baik pula. Hal ini didukung oleh Gusman dan Muhammad (2014) yang menyatakan bahwa hasil penelitian tingkat kelangsungan hidup pada ikan mas mencapai 83,33\%-96,67\%. Tingkat kelangsungan hidup pada ikan banyak dipengaruhi oleh faktor lingkungan, misalnya penanganan dan kualitas air. Penanganan yang salah dapat menyebabkan ikan stres, sehingga kondisi kesehatan ikan menurun dan dapat menyebabkan kematian.

\section{Kualitas Air}

Hasil pengamatan suhu selama pemeliharaan didapatkan kisaran $27^{\circ}-28^{\circ} \mathrm{C}$, dalam kondisi suhu perairan seperti itu kondisi perairan masih dalam kisaran yang layak untuk budidaya ikan mas (C. carpio). Suhu juga berpengaruh terhadap tingkat nafsu makan ikan dan daya tahan terhadap penyakit. Menurut Gusman dan Muhammad (2014) yang menyatakan bahwa nilai kualitas air menunjukkan bahwa parameter ini masih dalam batas kelayakan untuk kehidupan ikan mas. Kisaran kelayakan temperatur air bagi ikan mas adalah $14^{\circ}-38^{\circ} \mathrm{C}$.

Nilai $\mathrm{pH}$ pada media pemeliharaan berkisar $8,12-8,78$. Nilai $\mathrm{pH}$ tersebut masih berada pada kisaran normal. Nilai $\mathrm{pH}$ suatu perairan dapat mempengaruhi pertumbuhan bagi biota didalamnya, bahkan dapat menyebabkan kematian. Hal ini didukung oleh Copatti et al. (2011) yang menyatakan bahwa $\mathrm{pH}$ netral dan sedikit alkali direkomendasikan untuk ikan air tawar. Halini di dukung oleh Nirmala et al. (2012) bahwa pH mematikan bagi ikan adalah kurang dari 4 dan lebih dari 11, sedangkan pada $\mathrm{pH}$ kurang dari 6,5 dan lebih dari 9,5 dalam beberapa jam akan mempengaruhi pertumbuhan dan reproduksi ikan.

Oksigen terlarut atau Dissolved Oxygen (DO) merupakan salah satu variabelpenting dalam menentukan kualitas air.Hasil pengukuran oksigen terlarut selama pemeliharaan didapatkan kisaran antara 6,2-7,8 mg/L.Kadar oksigen terlarut tersebut masih dalam kadar normal. Menurut Sulawestyet al. (2014) yang menyatakan bahwa kandungan oksigen terlarut untuk pemeliharaan ikan mas adalah 2,5-7,1 mg/L. Menurut Rudiyanti dan Astir, (2009) yang menyatakan bahwa kandungan oksigen dalam suatu perairan minimum sebesar $2 \mathrm{mg} / \mathrm{L}$, sudah cukup mendukung terhadap organisme perairan secara normal.

Amonia $\left(\mathrm{NH}_{3}\right)$ dalam perairan berasal dari feses ikan maupun sisa pakan.Hasil pengukuran menunjukkan 
nilai amonia pada kisaran 0,0011-0,0023 mg/L. Nilai tersebut masih berada dalam kisaran normal pada habitat ikan mas $(C$. carpio).Hal ini didukung oleh Rudiyanti dan Astri, (2009) yang menyatakan bahwa kisaran konsentrasi ammonia yang baik untuk kehidupan ikan adalah kurang dari 2,4 mg/L.Ammoniayang berada dalam jumlah yang relatif kecil bersifat toksik terhadap ikan.

\section{KESIMPULAN DAN SARAN}

\section{Kesimpulan}

Kesimpulan yang dapat diambil dari penelitian "Pengaruh Periode Pemuasaan Terhadap Efisiensi Pemanfaatan Pakan, Pertumbuhan dan Kelulushidupan Ikan Mas (Cyprinus carpio)" adalah sebagai berikut:

1. Periode pemuasaan berpengaruh nyata $(\mathrm{P}<0,05)$ terhadap efisiensi pemanfaatan pakan, pertumbuhan, namun tidak berpengaruh nyata terhadap kelulushidupan ikan Mas (C. carpio).

2. Perlakuan A (tanpa dipuasakan) memberikan nilai TKP tertinggi sebesar $126,30 \pm 5,25 \mathrm{~g}$, nilai RGR tertinggi

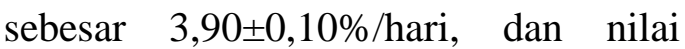
pertumbuhan panjang mutlak tertinggi sebesar 3,96 $\pm 0,01 \mathrm{~cm}$. Perlakuan B (dipuasakan 1 hari diikuti pemberian pakan 1 hari) memberikan nilai EPP tertinggi sebesar $76,44 \pm 2,46 \%$, dan nilai FCR terrendah sebesar 1,22 $\pm 0,04$.

\section{Saran}

Saran yang dapat diberikan dalam penelitian ini adalah:

1. Sebaiknya pada pemuasaan ikan mas (C. carpio) menggunakan periode 1 hari dipuasakan dan 1 hari diberi pakan karena bisa memberikan nilai efisiensi pemanfaatan pakan yang lebih baik.

2. Perlu dilakukan penelitian lebih lanjut untuk mengetahui pengaruh pemuasaan pada ikan mas $C$. carpio) terhadap kinerja enzim pencernaan.

\section{UCAPAN TERIMA KASIH}

Terima kasih penulis ucapkan kepada Bapak Ir. Nurdwi Esto, selaku kepala Balai Benih Ikan (BBI) Mijen, Semarang yang telah menyediakan tempat dan fasilitas untuk pelaksanaan penelitian ini dan semua pihak yang telah membantu kelancaran penelitian ini.

\section{DAFTAR PUSTAKA}

Afifah, B., N. Abdulgani, dan G. Mahasri. 2014. Efektifitas Perendaman Benih Ikan Mas (Cyprinus carpio L.) dalam Larutan Perasan Daun Api-api (Avicennia marina) Terhadap Penurunan Jumlah 
Trichodina sp.Jurnal Sains dan Seni Pomits. 3(2): 2337-3520 hlm.

Copatti, C. E., L. O. Garcia, D. Kochhann, M. A. Cunha, A. G. Becker, and B. Baldisserotto. 2011. Low Water Hardness and $\mathrm{pH}$ Affect Growth and Survival of Silver Catfish Juveniles. 1482 Ciência Rural. 41(8): 1482-1487 p.

Effendie, H. 1997. Telaah Kualitas Air bagi Pengelolaan Sumber Daya dan Lingkungan Perairan. Cetakan Kelima. Kanisius, Yogyakarta. $259 \mathrm{hlm}$.

Gusman, E. dan Muhammad Firdaus, 2014. Pemanfaatan Buah Mangrove sebagai Campuran Pakan untuk Meningkatkan Pertumbuhan Ikan Mas (Cyprinus carpio). Jurnal Harpodon Borneo. 07(01): 27-35 hlm.

Hanief, M. A. R. Subandiyono, dan Pinandoyo. 2014. Pengaruh Frekuensi Pemberian Pakan Terhadap Pertumbuhan Dan Kelulushidupan Benih Tawes (Puntius javanicus). Journal of Aquaculture Management and Technology. 03(04): 67-74 hlm.

Hanum, W. M, U. Susilo, dan S. Priyanto. 2013. Aktivitas Protease dan Kadar Protein Tubuh Ikan Lele Dumbo (Clarias gariepinus) pada Kondisi Puasa dan Pemberian Pakan Kembali. Fakultas Biologi. Universitas Jenderal Soedirman, Purwokerto. 1-7 hlm.

Juwitanti E, C. Ain, P. Soedarsono. 2013. Kandungan Nitrat dan Fosfat Air pada Proses Pembusukan Eceng Gondok (Eichhornia Sp.) (Skala Laboratorium). J. Of Maquares. 2(4): 46-52 hlm.
Marwa, H. Salamet, dan Hariyano. 2013. Pengaruh Frekuensi Pemberian Pakan Terhadap Pertumbuhandan Survival Rate Benih Ikan Mandarin (Synchiropus splendidus). Program Pascasarjana Program Studi Ilmu Kelautan. Universitas Pattimura. Ambon. 6-8 hlm.

Maulidin, R., Z. A. Muchlisin, dan A A. Muhammadar. 2016. Pertumbuhan dan Pemanfaatan Pakan Ikan Gabus (Channa striata) Pada Konsentrasi Enzim Papain Yang Berbeda. Jurnal Ilmiah Mahasiswa Kelautan dan Perikanan Unsyiah. 1(3): 280-290 hlm.

Mudlofar F., Erlinda Yurisinthae, Dan Agus Santoso. 2013. Analisis Usaha Pembesaran Ikan Mas (Cyprinus Carpio) pada Keramba Jaring Apung Di Kelurahan Parit Mayor, Kecamatan Pontianak Timur. Jurnal Eksos. IX(03): 153$175 \mathrm{hlm}$.

Mulyani, Y., S. Yulisman., dan M. Fitrani. 2014. Pertumbuhan Dan Efisiensi Pakan Ikan Nila (Oreochromis niloticus) Yang Dipuasakan Secara Periodik. Jurnal Akuakultur Rawa Indonesia. 02(01): 01-12 hlm.

Nirmala, K., Yani, H., dan Riza P. W. 2012. Penambahan Garam dalam Air Media yang Berisi Zeloit dan Arang Aktif pada Transportasi Sistem Tertutup Benih Ikan Gurami (Oshpronemus goramy Lac.). Jurnal Akuakultur Indonesia. 11(02): 190-201 hlm.

Pereira, L., T. Riquelme and H. Hosokawa. 2007. Effect of There Photoperiod Regimes on the Growth and 
Mortality of the Japanese Abalone (Haliotis discus hanaino). Kochi University, Aquaculture Department, Laboratory of Fish Nutrition, Japan. 26: 763-767 p.

Purbomartono, C., Hartoyo, dan Agus K. 2009. Pertumbuhan Kompensasi pada Ikan Nila Merah (Oreochromis niloticus) dengan IntervalWaktu Pemuasaan yang Berbeda. Jurnal Perikanan (J. Fish. Sci.). XI(01): 19-24 hlm.

Puspasari, T., Y. Andriani, H. Hamdani. 2015. Pemanfaatan Bungkil Kacang Tanah Dalam Pakan Ikan Terhadap Laju Pertumbuhan Ikan Nila (Oreochromis niloticusi). Jurnal Perikanan Kelautan. 06(02): 91-100 hlm.

Rudiyanti, S. dan Astri D. E., 2009. Pertumbuhan dan Survival Rate Ikan Mas (Cyprinus Carpio Linn) pada Berbagai Konsentrasi Pestisida Regent 0,3 G. Jurnal Saintek Perikanan. 05(01): 39-47 hlm.

Sanjayasari, D., 2010. Pengaruh Prebiotik pada Populasi Mikroflora Saluran Pencernaan Ikan Mas (Cyprinus Carpio) serta Kontribusinya Terhadap Efisiensi Retensi Protein dan Pertumbuhan. [Tesis]. Institut Pertanian Bogor. Bogor. 5-20 hlm.

Silvianti, T., 2015. Evaluasi Penambahan Ragi Bir Saccharomyces Cerevisiae Dalam Pakan Terhadap Kinerja Pertumbuhan Dan Daya Tahan Tubuh Ikan Mas Cyprinus Carpio Terhadap Infeksi Bakteri Aeromonas Hydrophila. Skripsi. Departemen Budidaya Perairan. Fakultas Perikanan Dan Ilmu Kelautan. Institut Pertanian Bogor. Bogor. 03-05 hlm.
Subandiyono dan S. Hastuti. 2014. Baronang Serta Prospek Budidaya Laut Di Indonesia. UPT Undip Press. Semarang. $86 \mathrm{hlm}$.

Sulawesty F., Tjandra Chrismadha, Dan Endang Mulyana, 2014. Laju Pertumbuhan Ikan Mas (Cyprinus Carpio L) dengan Pemberian Pakan Lemna (Lemna Perpusilla Torr.) Segar pada Kolam Sistem Aliran Tertutup. Jurnal Limnotek. 21(2): $177 \mathrm{hlm}$.

Sunarto dan Sabariah. 2012. Pemberian Pakan Buatan dengan Dosis Berbeda Terhadap Pertumbuhan dan Konsumsi Pakan Benih Ikan Semah (Tor Douronensis) dalam Upaya Domestikasi.Jurnal Akuakultur Indonesia. 08(01): 67$76 \mathrm{hlm}$.

Supriatna, Y. 2013. Budi Daya Ikan Mas di Kolam Hemat Air. Agromedia Pustaka. Jakarta. 3-5 hlm.

Tacon, A.G. 1987. The Nutrition and Feeding of Farmed Fish and Shrimp-A Traning Mannual. FAO of The United Nations, Brazil. $106-109$ p.

Widiastuti, I. M., 2009. Pertumbuhan dan Kelangsungan Hidup (Survival Rate) Ikan Mas (Cyprinus carpio) yang Dipelihara dalam Wadah Terkontrol dengan Padat Penebaran Yang Berbeda. Jurnal Media Litbang Sulteng. 02(02): 126-130 hlm.

Widyantoro, W. Sarjito, dan D. Harwanto. 2014. Pengaruh Pemuasaan Terhadap Pertumbuhan Dan Profil Darah Ikan Lele Dumbo (Clarias gariepinus) Pada Sistem Resirkulasi. Journal of Aquaculture Management and Technology. 3(2): 103-108 hlm. 
Yanti, Z., Z. A. Muchlisin, Sugito. 2013. Pertumbuhan dan Kelangsungan Hidup Benih Ikan Nila (Oreochromis niloticus) pada Beberapa Konsentrasi Tepung Daun Jaloh (Salix tetrasperma) dalam Pakan. Journal of Fisheries and AquaticSciences. 2(1): 16-19 hlm.

Yuwono, E. P. Sukardi, dan I. Sulistyo. 2005. Konsumsi Dan Efisiensi Pakan Pada Ikan Kerapu
Bebek(Cromileptes altivelis) Yang Dipuasakan Secara Periodik. Berk.Penel. Hayati. 10: 129-132 hlm.

Zaldua, N., and D.E. Naya. 2014. Digestive Flexibility During Fasting In Fish: A Review. Comparative Biochemistry and Physiology. Part A. 169: 7-14 p. 